\title{
Donor Status at Time of Organ Donation
}

National Cancer Institute

\section{Source}

National Cancer Institute. Donor Status at Time of Organ Donation. NCI Thesaurus.

Code C139269.

The donor's state or condition of being either living or brain dead at the time of organ harvesting. 